\title{
Website-Based E-Pharmacy Application Development to Improve Sales Services Using Waterfall Method
}

\author{
Suhirman ${ }^{1}$, Ahmad Tri Hidayat ${ }^{2}$, Wahyu Adjie Saputra ${ }^{3}$, Shoffan Saifullah ${ }^{4}$ \\ 1,3Informatics, UniversitasTeknologi Yogyakarta - Indonesia \\ ${ }^{2}$ Information System, UniversitasTeknologi Yogyakarta - Indonesia \\ ${ }^{4}$ Department of Informatics, Universitas Pembangunan Nasional Veteran Yogyakarta - Indonesia
}

\begin{abstract}
Article Info
Article history:

Received Sep 10, 2021

Revised Oct 15, 2021

Accepted Oct 30, 2021

\section{Keywords:}

E-Pharmacy

Online shop

HTML

MySQL

Software Development Life

Cycle

Waterfall

ABSTRACT

An online shop is a way of trading and shopping online via the internet. Online sales in the business sector will significantly help reduce operational costs, especially for customer activities; in its contribution to commerce, online sales can also increase selling power and widely facilitate the marketing of a product. "Seger Waras" Pharmacy is an agency engaged in the business of selling medicines and medical equipment. "Seger Waras" Pharmacy requires an online sales website or online store, which is intended to maximize service to existing or new customers. Therefore, the authors research the design of web-based drug sales systems at the "Seger Waras" Pharmacy. This study aims to increase the revenue of the relevant agencies and provide complete information about drug use to customers. Data collection methods use observation and interview methods for system models using Data Flow Diagrams, Entity Relationship Diagrams, and Context Diagrams. The software used by MySQL as a database server, Apache as a web server, Sublime Text 3 for writing PHP and HTML programming languages, and Bootstrap as a framework. The result of the system that has been completed is an online store application that makes it possible to sell and purchase drugs online; the online shop at the "Seger Waras" Pharmacy can increase sales turnover and promote business.
\end{abstract}

This is an open access article under the CC BY-SA license.

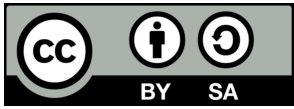

\section{Corresponding Author:}

Ahmad Tri Hidayat,

Department of Information System, Universitas Teknologi Yogyakarta, Jl. Siliwangi Jombor Sleman Yogyakarta.

Email: ahmad.tri.h@uty.ac.id

\section{INTRODUCTION}

There are many technology applications in the business sector, one of which is e-commerce [1]. E-commerce in the health sector was developed with an online pharmacy (e-pharmacy) [2]. One of the pharmacies currently developing is the Pharmacy "Seger Waras" that sells medicines and medical equipment, where every day there are conventional (manual) buying and selling transactions. The increase in the number of requests and transactions makes the Pharmacy "Seger Waras" maximize service performance to customers and improve its work scheme by creating an Online Pharmacy.

As with previous studies related to the development of online pharmacies [3] - [6]. Today's online pharmacies (pandemic COVID-19 [7], [8]) are very useful and necessary [9] - [11]. The development of an online pharmacy uses PHP programming and MySQL database [12], [13], 
which adopts the concept of System Development Live Cycle (SDLC). The development carried out starts from analysis, design, implementation, and maintenance [14], [15]. The online application of this system can impact the buying and selling process in particular pharmacies. However, each pharmacy has different rules and business processes, so that when implementing it, it has procedures and guidelines that are tailored to the place.

The "Seger Waras" Pharmacy records previous transactions using paper notes. The recap is recorded in a book, and the data on drug purchases from suppliers is written in the defect book, which can lead to fraud. Besides, it is also difficult to directly monitor the running business and monitor the availability of drugs in pharmacies to develop online pharmacies using a web-based or online sales system. Pharmacy at "Seger Waras" pharmacies is expected to increase revenue, service quality, facilitate transaction reporting, and compete with other pharmacies. Following the above discussion, the purpose of this study is to design and build a drug service information system that has easy access to the user and implement it to support work efficiency at the "Seger Waras" Pharmacy.

\section{RESEARCH METHOD}

This study uses a website-based design on the information system development method. The objects used are the sale and purchase transactions of drugs and the storage of drug stocks from the Pharmacy "Seger Waras". Data collection was carried out using three concepts, namely: interviews, observation, and literature study. Thus, the result is a research process with system design, database design, interface design, and implementation.

System design aims to provide a general and precise description or modeling of a system to make it easier for users to process the created and implemented data. The online pharmacy process flow is explained using the Data Flow Diagram (DFD) method and an overview of database design using the Entity-Relationship Diagram (ERD). Database design discusses entity-relationship diagrams, relationship tables, and table structures. In the drug stock itself, the table is needed for the product, category, type, stock, purchase, date, and needs using sales reports, purchases, and invoices.

Interface design contains the main menu design, input, process, and output. Interface design or interface includes designing the main menu structure and designing the display on the user interface. User access includes the head of the pharmacy and employees. The input design is the initial design for the start of the information process. The raw material of information is data that occurs from transactions. In this input process, it pays close attention to the order of goods in and out and the goods' validity period. Besides, detailed input design starts from basic document design as a first-time input catcher. If the base document is not designed correctly, there is a possibility that the recorded input could be incorrect or redundant.

Process Design is processing input data into information or knowledge. Once processed, the resulting data must have informative value when stated and packaged in an organized and neat manner. The drug data is processed into inventory information. Output design is the result of data processing that has been done in the form of reports that will be addressed to the user. Implementing the system is expected to make it easier for users to monitor drug supplies in pharmacies. The system provides data input for drugs, stocks, expenses, and statistics on the estimated number of transactions for the next period. Before being implemented, the system needs to be tested. The test method used in developing this application is black-box testing. Black box testing or functional tests are carried out only by observing the results of execution through test data and checking the application's functionality.

Program testing in this web application is carried out by the developer and the user to provide data to be processed. The things that are of concern in testing are as follows:

1. Website can make input based on drug code, the same type, and name of goods may have different drug code with attention to the first in first out and validity period of the drug.

2. Test the data structure and access the database with valid data.

3. Discussion process with users so that the system can run properly according to field needs. 
4. The website can provide transaction information, drug data, and calculation of the chances of selling drugs for the next period

The concept of e-commerce McLeod, P (2009) [16] uses communication networks and computers to carry out business processes. E-commerce uses the internet and computers with web browsers to introduce, offer, buy and sell products. Meanwhile, e-commerce can also be interpreted as the application of e-business as a strategy of buying and selling goods and services through electronic networks and usually involves electronic data transactions, automatic inventory management systems, and automatic data collection systems. E-commerce electronic commerce includes the process of buying, selling, transferring, or exchanging products, services, or information through computer networks, including the internet [17].

In this study, the method used is the waterfall method, where this method is a classical model that is systematic, sequential in building software. The waterfall model or Linear Sequential Model is often called the "Classic Life Cycle" [18]. Winston Royce first introduced this model around 1970, so it is considered outdated, but it is the model most widely used in Software Engineering to date. The waterfall method's essence is that the work of a system is carried out sequentially because it is completed step by step, which must wait for the completion of the previous stage (Figure 1).

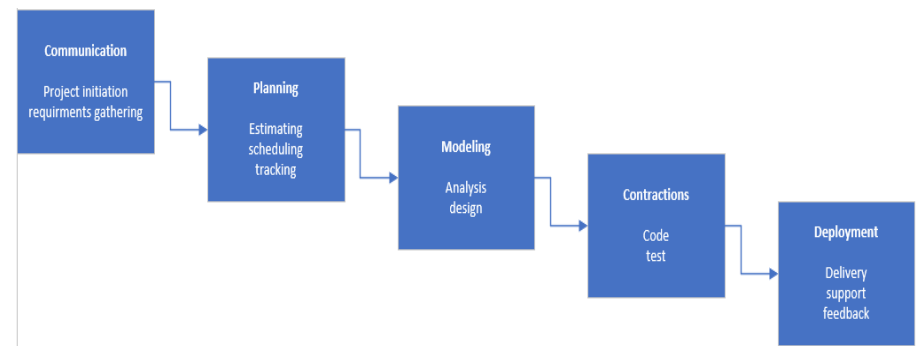

Figure 1. The waterfall method process flow from Pressman (2010) [18].

This method is applied in making websites. Website or site [19] is a collection of pages that display information. It is static if the content of website information remains and rarely changes. It is dynamic if the content of website information is always changing, and there is a twoway interaction between the owner and the user.

Making the website requires a database collection of data (elementary), which is logically related to presenting phenomena/facts in a structured manner in specific domains to support applications on individual systems [20]. The database is also a significant component of information systems because all decision-making information comes from the database's data. Low database processing can result in the unavailability of essential data used to produce information needed in decision making.

Interface design uses an API (Application Programming Interface). API is an interface built by system developers so that part or all of the system functions can be accessed programmatically [21]. API can also be analogous to software with an interface, where the interface is used to access all resources or instructions in the software. With the API, the software can interact with other software with specific instructions or rules to access resources through an existing interface.

The payment gateway is a service that authorizes payments in e-business and online retail [22]. Payment gateways are equivalent to POS (point-of-sale) located at outlets or merchants. Generally, payment gateways have two components, namely:

1. A virtual terminal allows a merchant to keep logins and keys secure on credit card numbers.

2. A shopping cart website connected to a payment gateway via an API, allowing real-time processing.

Point of sale (POS) itself usually from a set of cash registers, complete with a cash drawer and a machine to print receipts, but with the current development. The POS system is not only in 
the form of offline software but has developed into an online software widely adopted by Payment Gateway. The flow can be seen in Figure 2.

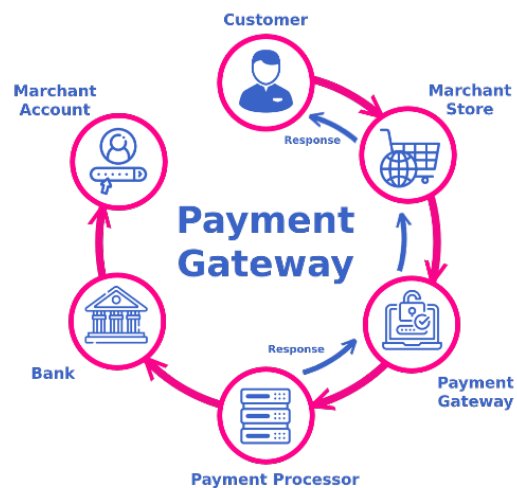

Figure 2. Payment gateway flow (Source: Business Paytm)

A pharmacy is a specific place where pharmaceutical work is carried out in distributing pharmaceutical supplies to the public. Pharmaceutical works are in the procurement of drugs, drug storage, manufacturing of drug preparations, compounding, distribution and delivery of pharmaceutical supplies, and providing information to the public regarding pharmaceutical supplies consisting of drugs, medicinal ingredients, traditional medicines, medical devices, and cosmetics.

a. Procurement of goods or drugs at a pharmacy uses a salesman system by coming to the pharmacy or by telephone, the problem that sometimes occurs is the unavailability of supply from the factory if the place an order suddenly, therefore ordering drugs from long ago

b. storage of medical devices and drugs in pharmacies is arranged alphabetically and based on specific groups.

c. Drug storage is carried out based on drug classes such as over-the-counter drugs, limited-free drugs, hard drugs, and narcotic drugs.

d. Alphabetical storage of medicines is made to make it easy to find and organize medicines.

e. Storage classifications for drugs are based on syrup preparation, ointment, injection, liquid, etc.

f. Storage based on storage temperature is carried out for certain drugs such as suppositories and insulin stored in the refrigerator. Room temperature does not damage the shape and properties of the drug.

g. Drug distribution in pharmacies is divided into two ways, namely:

i. A written request from a doctor for a pharmacy is then handed over to the patient in the form of a finished medicine.

ii. Non-prescription drugs that are traded freely without a doctor's prescription.

h. Reporting at the pharmacy consists of 2 parts, namely:

i. Daily reports were containing data on sales, drug expenditure, and drug intake. Medicines are recorded in the morning. The drugs that go out and enter the pharmacy are recorded in a book in the afternoon. The drugs given to patients must be recorded in a dispensing book that will be recapitulated every month.

ii. Monthly reports contained reports on the entry and release of drugs classified as Narcotics and Psychotropics.

Medicine is a substance or combination of materials, including biological products used to influence or investigate physiological systems or pathological conditions in the framework of determining a diagnosis, prevention, cure, recovery, health improvement, and contraception for humans. In a general sense, medicine is a substance that, through its chemical effect, brings about changes in biological function.

Drugs are classified into four categories, namely: 
OTC drugs are sold freely in the market and can be purchased without a doctor's prescription. The unique mark on OTC drugs' packaging and the label is a green circle with a black outline. Example: Paracetamol.

Limited over-the-counter drugs are drugs that actually include hard drugs but can still be sold or purchased over the counter without a doctor's prescription and accompanied by warning signs. The package's unique mark and label of limited OTC drugs is a blue circle with a black outline. Example: CTM

Hard drugs are drugs that can only be purchased at pharmacies with a doctor's prescription. The unique mark on the packaging and label is the letter $\mathrm{K}$ in a red circle with a black outline. Example: Mefenamic Acid.

Psychotropic drugs are hard drugs, both natural and synthetic, not narcotics, which have psychoactive properties through selective effects that cause unprecedented changes in mental activity and behavior. Examples: Diazepam, Phenobarbital.

Narcotic drugs are drugs derived from plants or non-plants, both synthetic and semisynthetic, which can cause a decrease or change in consciousness, loss of taste, reduce pain and cause dependence.

\section{RESULTS AND DISCUSSION}

\subsection{System Analysis}

In system analysis, there are two analyzes, namely the running system and requirements. The Pharmacy "Seger Waras" only serves the purchase of products directly with customers coming to the pharmacy or order via WhatsApp messages. All data on sales and purchase transactions of drugs are even recorded in books. Through current technological developments and encouragement from the times that have increasingly tightened business competition, the Seger Waras Pharmacy is encouraged to renew its work scheme by changing conventional systems to computerized ones.

During its development, the pharmacy owner requested a web-based sales application for "Seger Waras" Pharmacy. This website hopes that the marketing of products from the Pharmacy Seger Sane can be more widespread and can increase sales. In developing the online pharmacy, the system requires several functional and non-functional requirements, as shown in Table 1.

Tabel 1. Requirements of The Pharmacies Development

\begin{tabular}{|c|c|c|}
\hline \multirow{2}{*}{ Requirements } & \multicolumn{2}{|r|}{ Detail } \\
\hline & Item & Description \\
\hline \multirow{6}{*}{ Functional } & Account list & Input name, username, password, email, and photo \\
\hline & Login & Input username and password \\
\hline & Address & input complete address \\
\hline & Order & Drug name, drug tyoe, and the amount of the order \\
\hline & Payment & Input name, invoice number, bank, proof of payment \\
\hline & Output data & $\begin{array}{l}\text { Report information which contains details in the form of name, address, } \\
\text { telephone number, courier, drug name, sub-total, postage, and total } \\
\text { payment }\end{array}$ \\
\hline \multirow{5}{*}{$\begin{array}{l}\text { Non- } \\
\text { Functional }\end{array}$} & Sublime Text & Tools with PHP, HTML and CSS languages \\
\hline & DBMS & MySQL as a database programming language \\
\hline & $\begin{array}{l}\text { Microsoft } \\
\text { Visio }\end{array}$ & The designer of ERD, DFD, Level Diagram and Inter-table Relations \\
\hline & Balsamic & Interface designer \\
\hline & Bootstrap 4 & HTML and CSS based framework \\
\hline
\end{tabular}

\subsection{System Design}

The system design was carried out by designing the ERD and DFD. ERD is a tool used to model data structures by describing entities and relationships between entities (relationship) abstractly (conceptually). ERD is used to describe the relationship between data in the database, as seen in Figure 3. 
Data Flow Diagram (DFD) Level 1 describes the data flow and data storage flow from the system to the database. The data flow diagram (DFD) level 1 describes the access rights of the admin and customer of the Pharmacy Seger Sane. Admin can process master data, transaction data, access reports, while customers can access drug information, make orders and pay transactions, as shown in Figure 4.

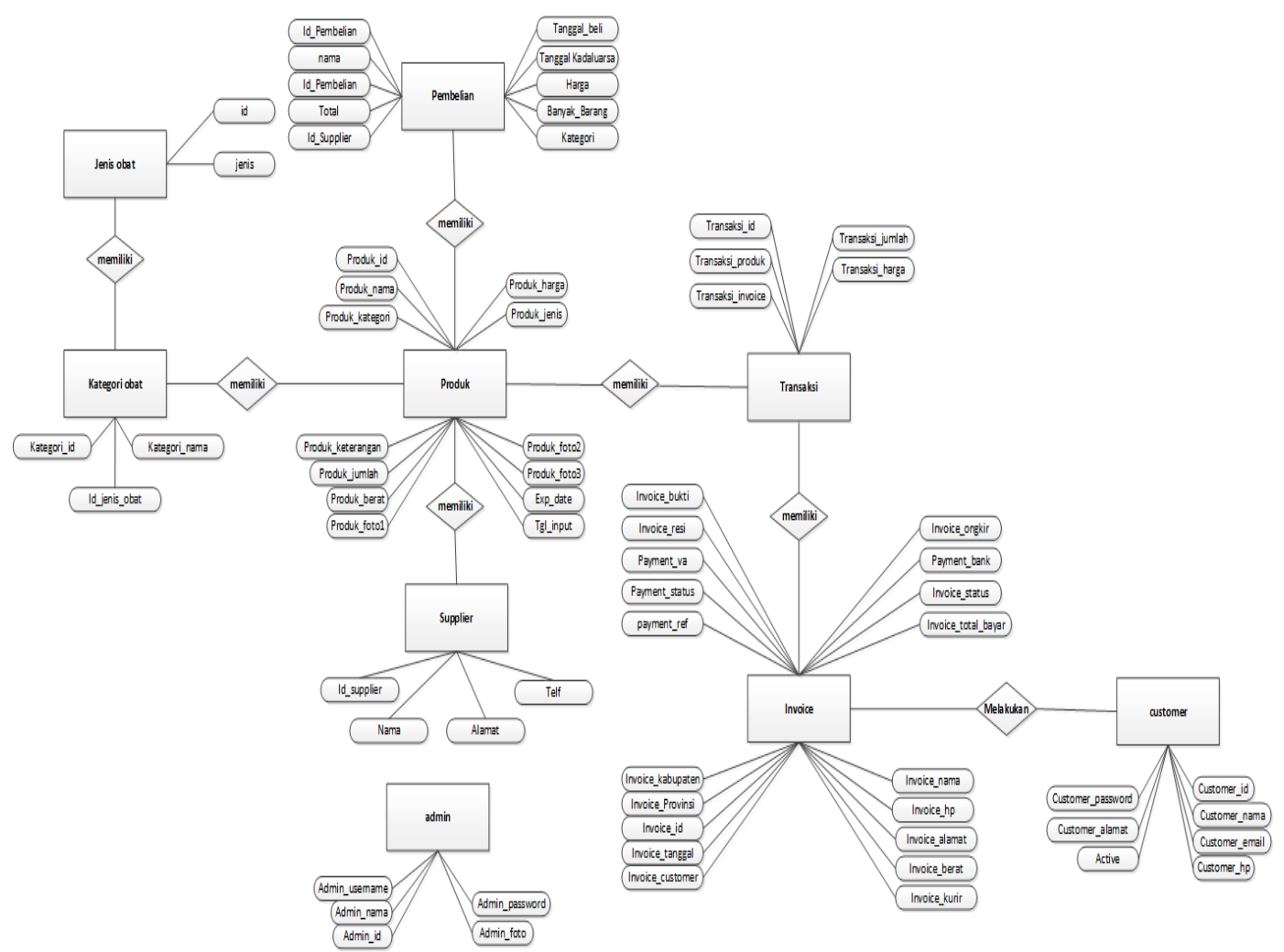

Figure 3.ERD online pharmacy "Seger Waras"

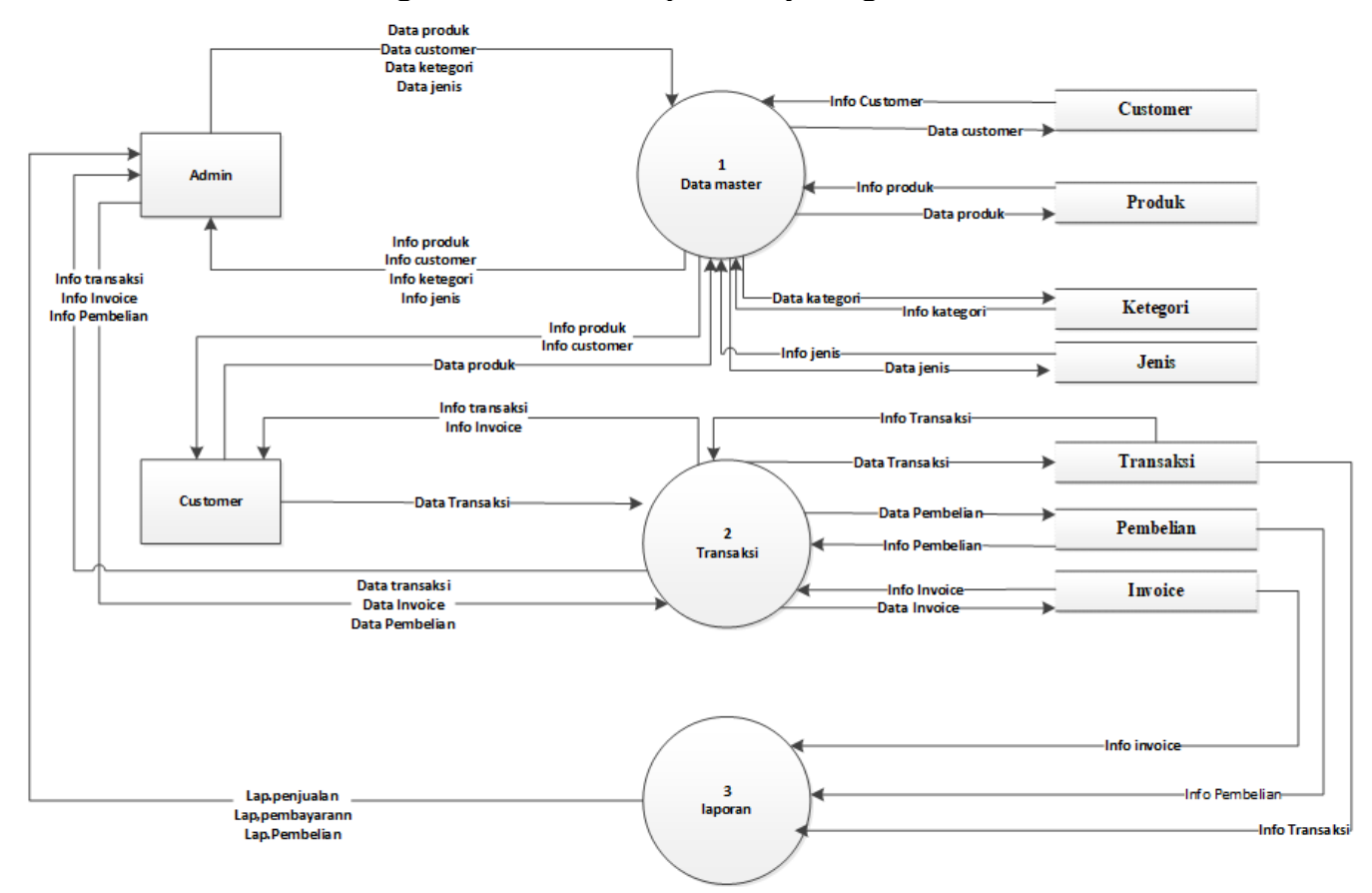

Figure 4.DFD Level 1

Data flow diagram (DFD) level 2 process 1 is a master data processing with 6 data processes. The first process is admin data processing, second product data collection, third 
customer data collection, fourth category data collection, fifth type data collection, and finally supplier data collection. The master data is stored and displayed by the system later. DFD level 2 process 1 is shown in Figure 5.

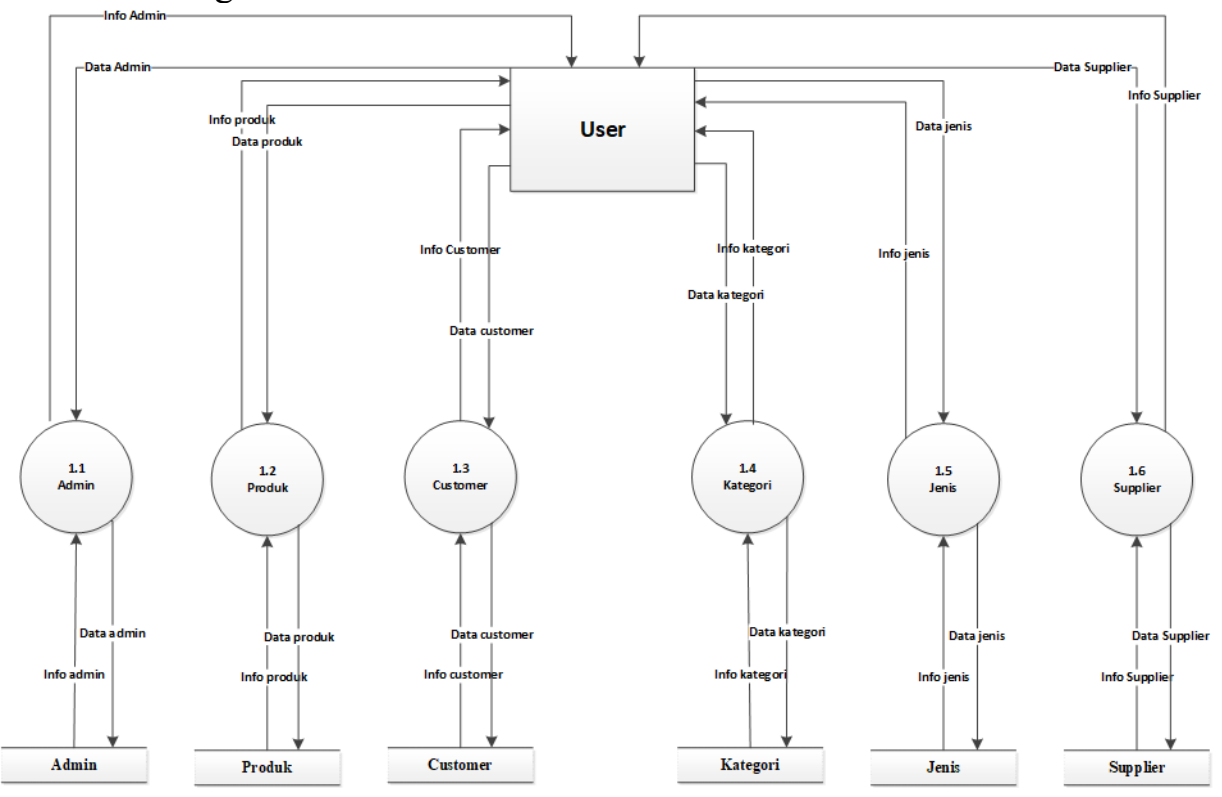

Figure 5.DFD Level 2 Process 1

Data flow diagram (DFD) Level 2 process 2 describes the transaction data processing, which has 3 data processes. First, the transaction process, the transaction here contains payment and order data. The second, the product purchasing process. The third is the invoice process, which contains all the customer's transaction data, as shown in Figure 6.

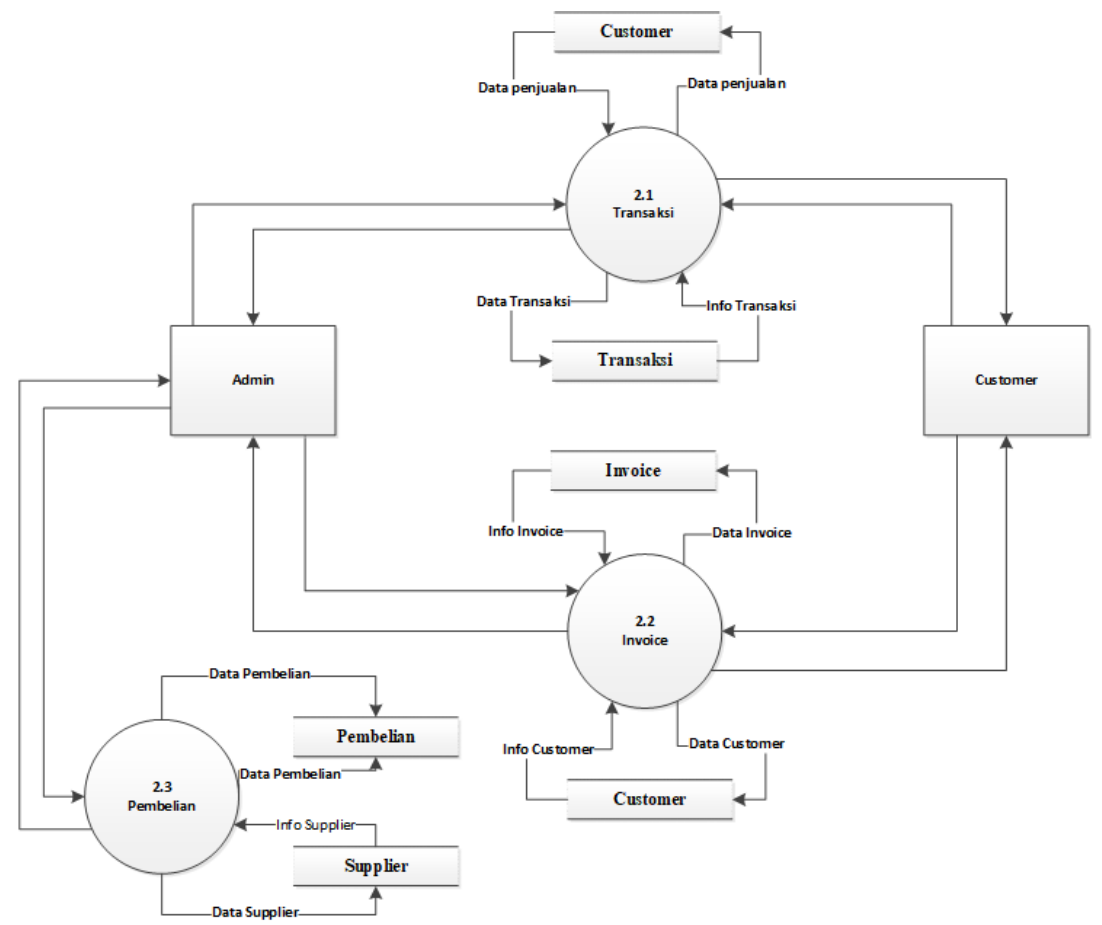

Figure 6.DFD Level 2 Process 2

The data flow diagram (DFD) Level 2 Process 3 is explained that the owner/admin can receive all information on daily, weekly, or monthly sales reports, order reports, and payments 
made by customers and see the status of payments paid off or not. The process can be seen in Figure 7.

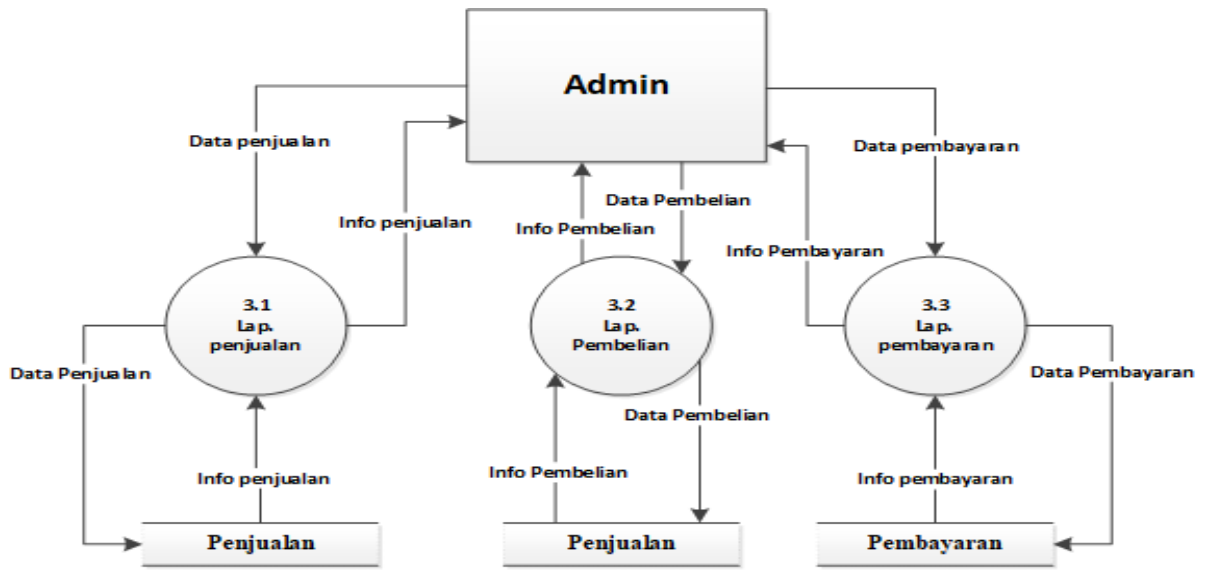

Figure 7.DFD Level 2 Process 3

\subsection{System Implementation}

This web-based drug sales system's function is to market products from pharmacies online to make it easier for customers to buy products from "Seger Waras" Pharmacy. From this system, customers can get detailed drug information before making a purchase. All of the data entered into the MySql database. Before customers can make purchases on this system, customers must register for an account and verify their email to log in. To make payments, customers can choose online payment options by bank transfer via a virtual account number or offline using a unique code by coming to the nearest Indomaret or Alfamart. API Raja Ongkir provides delivery services.

This index page in the header displays a menu of product search, customer registration, customer login, the body displays data on products sold, including price, name, product description, and on the footer displays link button options for cart, order, about, and delivery. The index page can be seen in Figure 8.

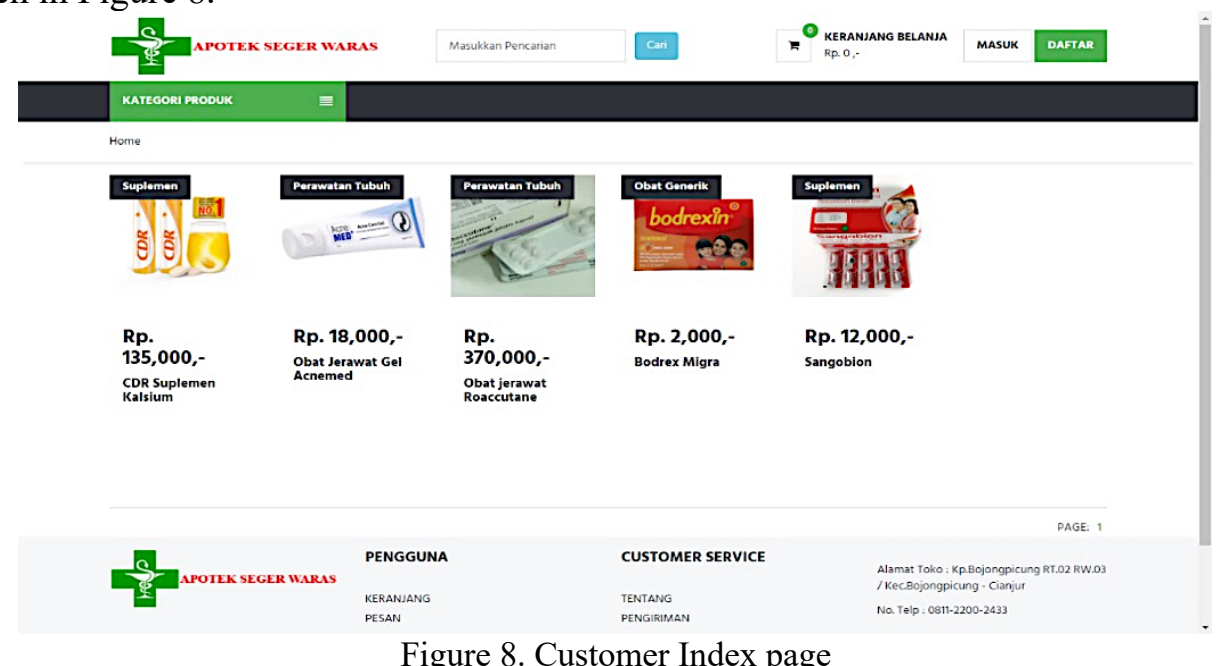

Figure 8. Customer Index page

This customer login page consists of a text field for inputting a username and password, one login button. When the customer presses the login button or enters, there is a process at input_act.php that will verify the data under certain conditions so that the customer can successfully log in or not. The customer login page can be seen in Figure 9. 


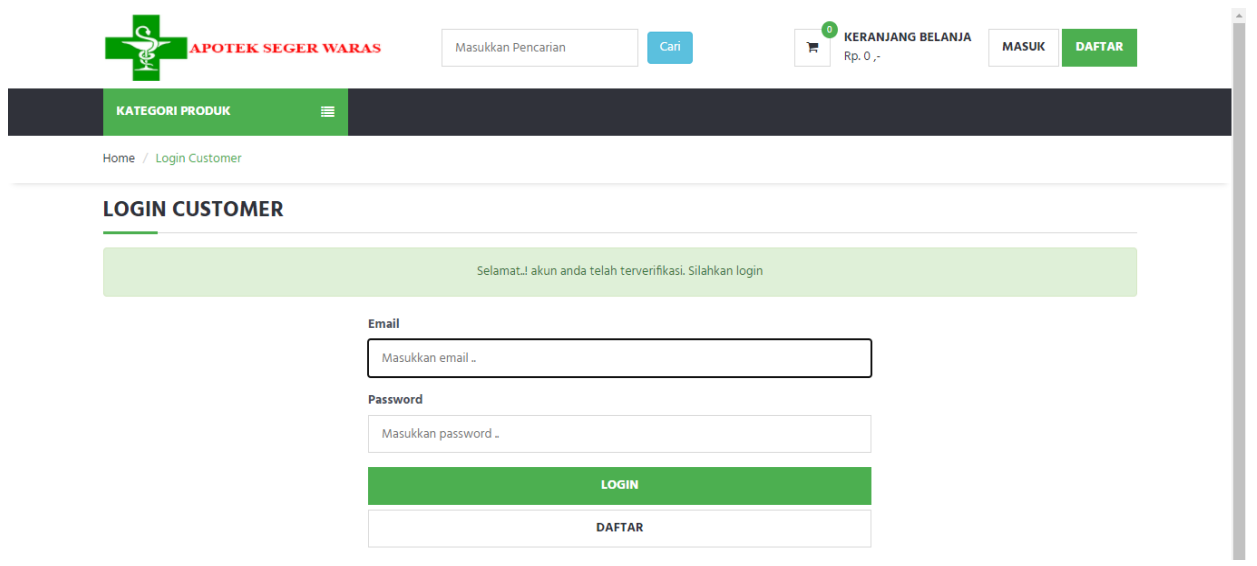

Figure 9. Customer Login Page

The customer profile page displays data from customers such as full name, address, mobile number, and email. There is an order page to monitor transactions made and get the VA number required for payment. The customer profile page can be seen in Figure 10.

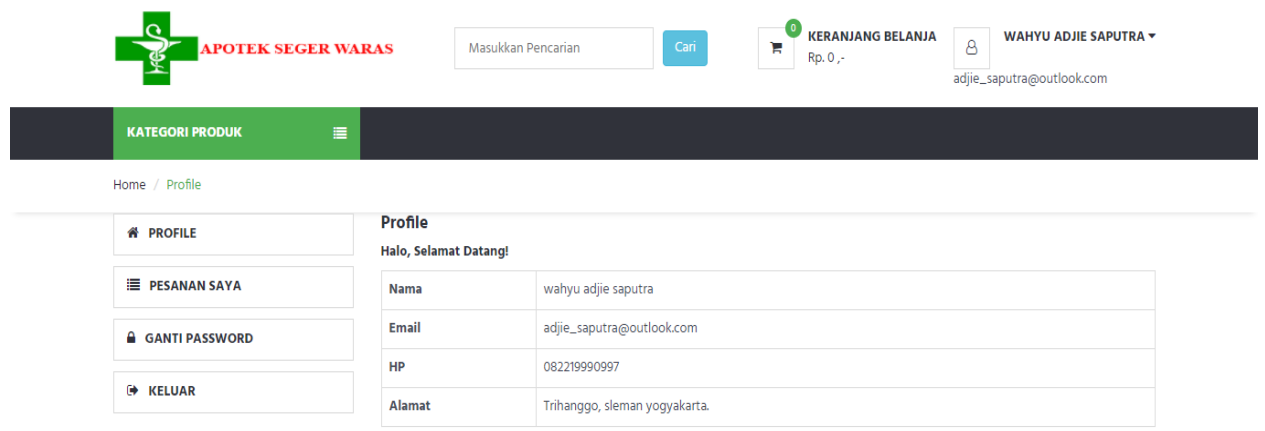

Figure 10. Customer Profile Page

The basket page displays the products that have been entered and are ready to be paid. On this page, the customer can update the number of products to be purchased or delete them. The total price will be updated based on the number of items multiplied by the price listed. The basket page can be seen in Figure 11.

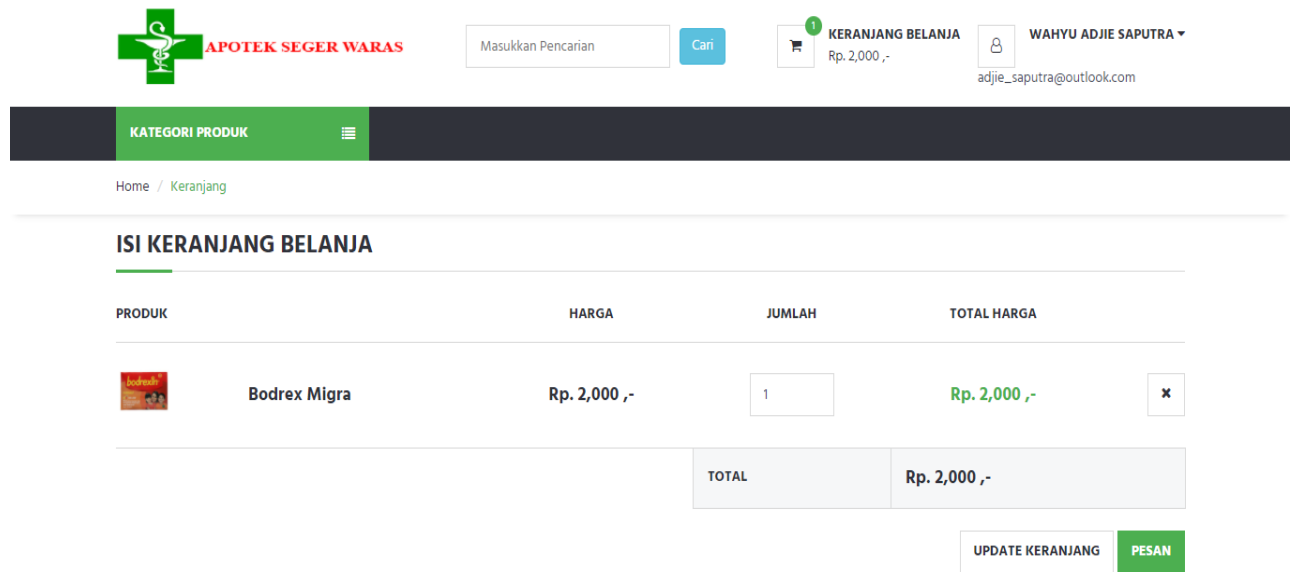

Figure 11. Basket page

This order page displays data on items to be purchased along with prices. Before making a purchase, customers must enter their data and address for shipping purposes, and customers can 
also choose the desired courier service and payment method. The order page can be seen in Figure 12 and Figure 13.

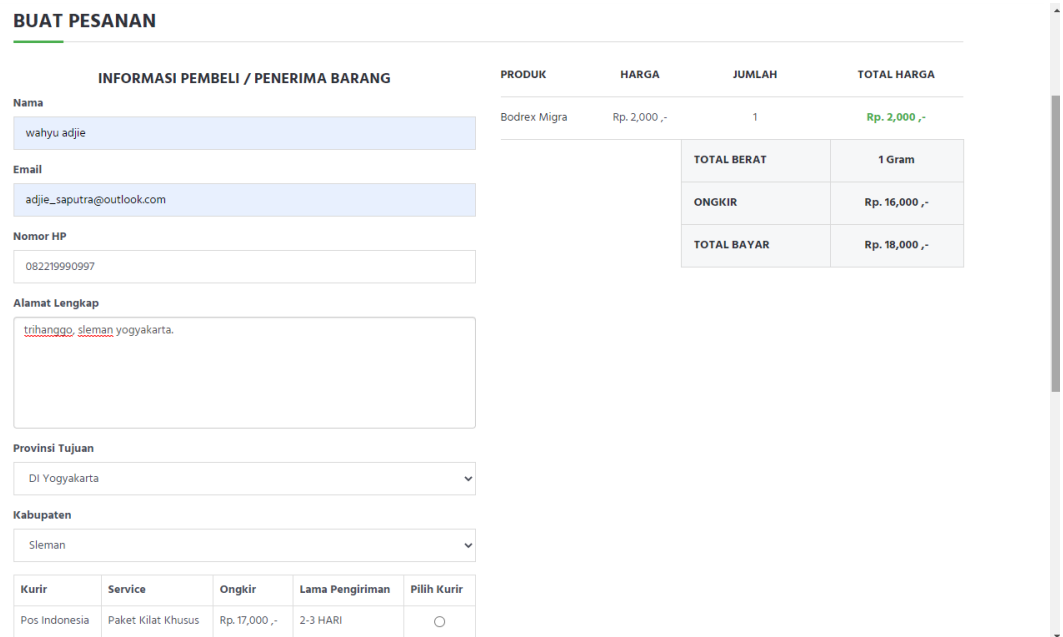

Figure 12. The Order Page

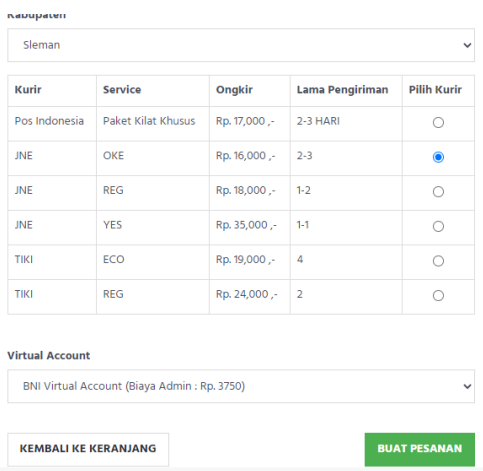

Figure 13. The Order Page

The order page displays a list of transactions that the customer has made, displays the invoice number, date, recipient name, total payment, bank, virtual account number, receipt, payment status, and print invoice. The order page can be seen in Figure 14.

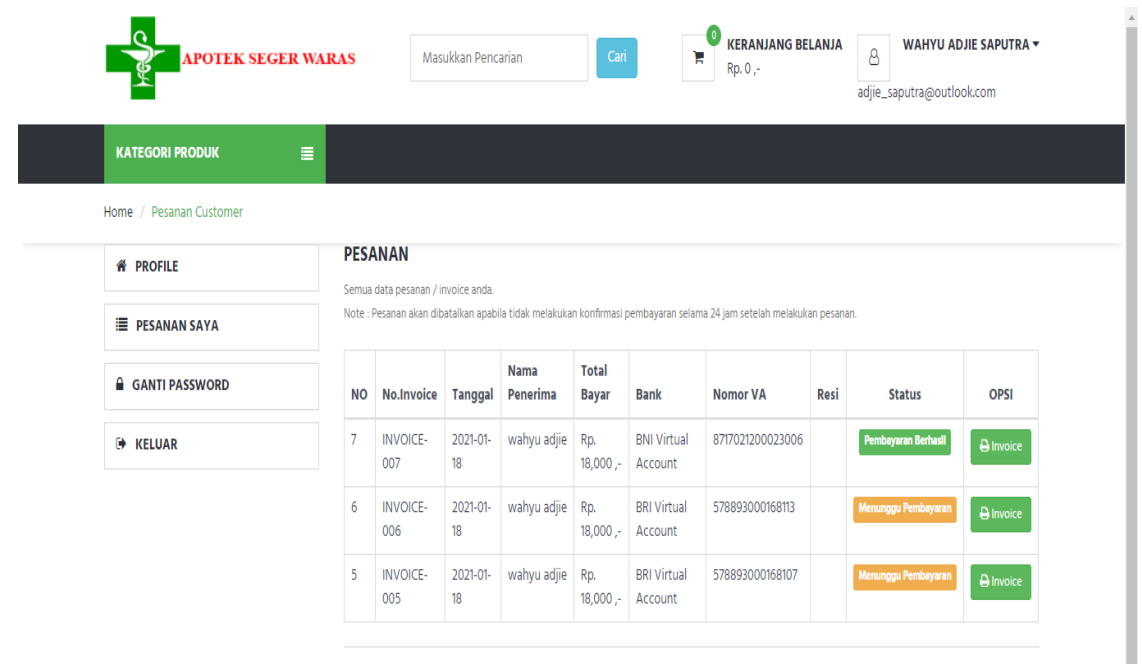

Figure 14. My Orders page 
This page displays the product's name to be purchased and the customer's total price to be paid. Following the customer's payment method, a payment number will appear, such as a virtual account number for the bank or a reference number for payments via Alfamart or Indomaret. The page of payment notes and proof of payment can be seen in Figure 15 and Figure 16.

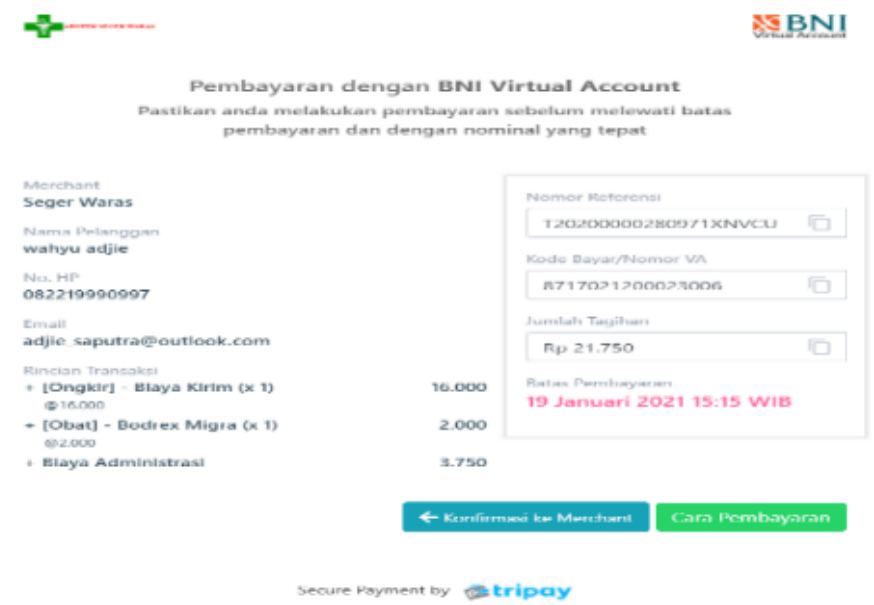

Figure 15. Payment Note Page

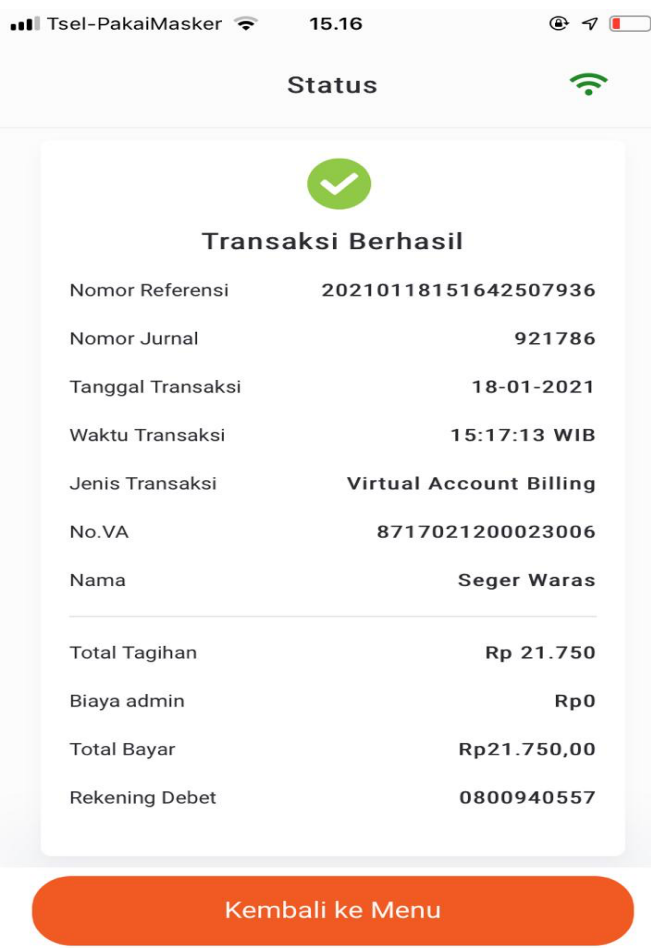

Figure 16. Proof of Transaction with a VA Number

The admin login page is the first display when a user accesses the admin page, with two text field components for entering a username and password. The login button functions to process existing input; when the input matches the database's data, it will be redirected to the dashboard page. If not, a warning message will appear so that the user can input valid data. Admin login page can be seen in Figure 17. 


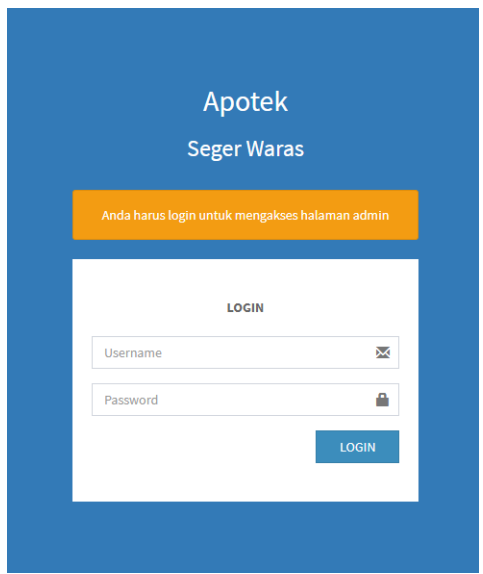

Figure 17. Admin Login Page

The main page is a form that appears after the user has successfully passed the previous login page, here it displays various menus for editing data that the admin can only access. Admin page can be seen in Figure 18.

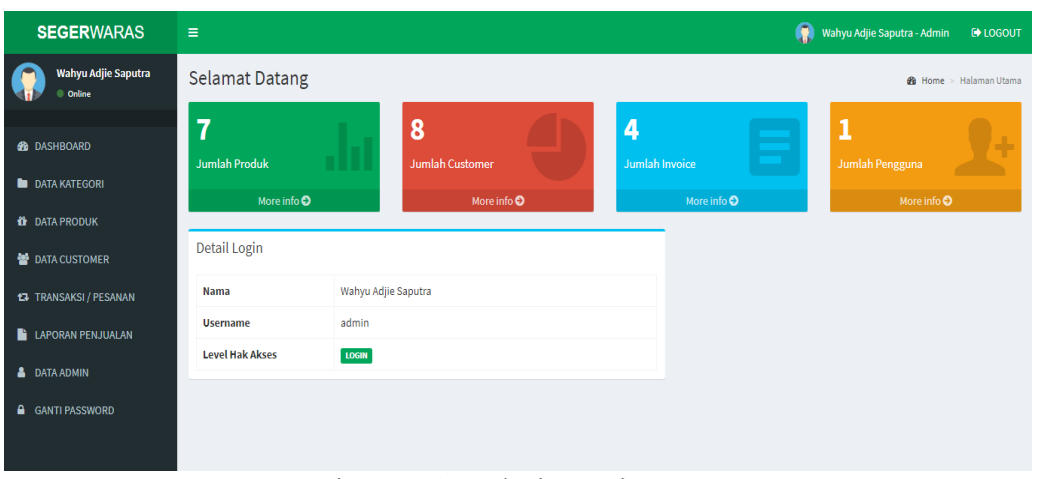

Figure 18. Admin Main Page

The category data page is a menu where the admin can input existing item data categories to make it easier to categorize the items to be inputted later. The category data page can be seen in Figure 19.

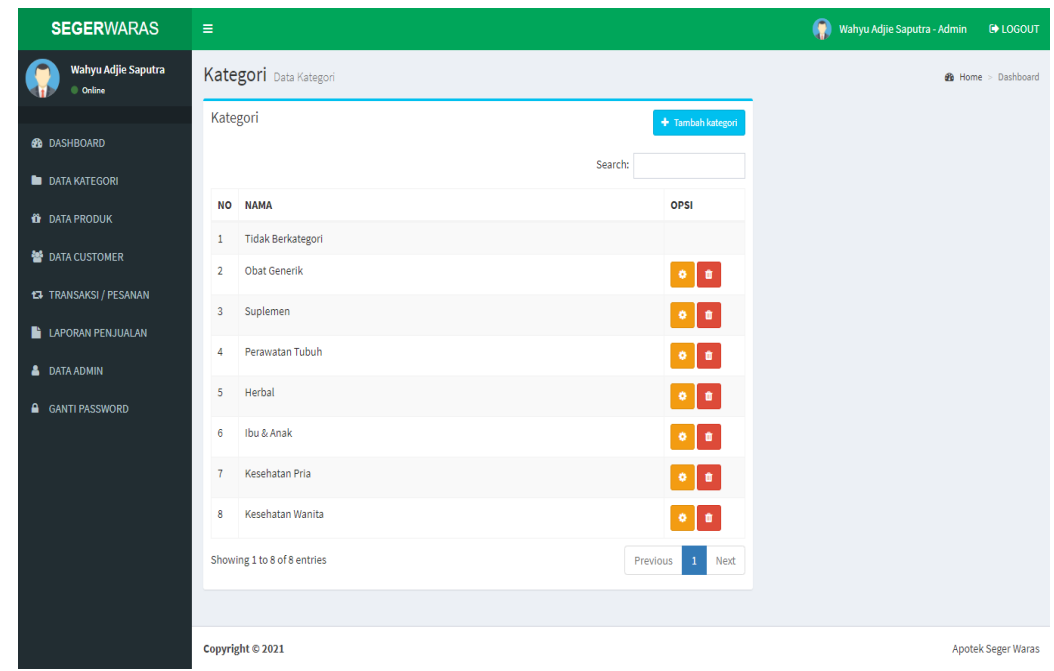

Figure 19. Category Data Page

The product data page is a menu where the admin inputs product data to be sold or displays on the customer index page. The data in question is data that has been stored before the system is built. The product data page can be seen in Figure 20. 


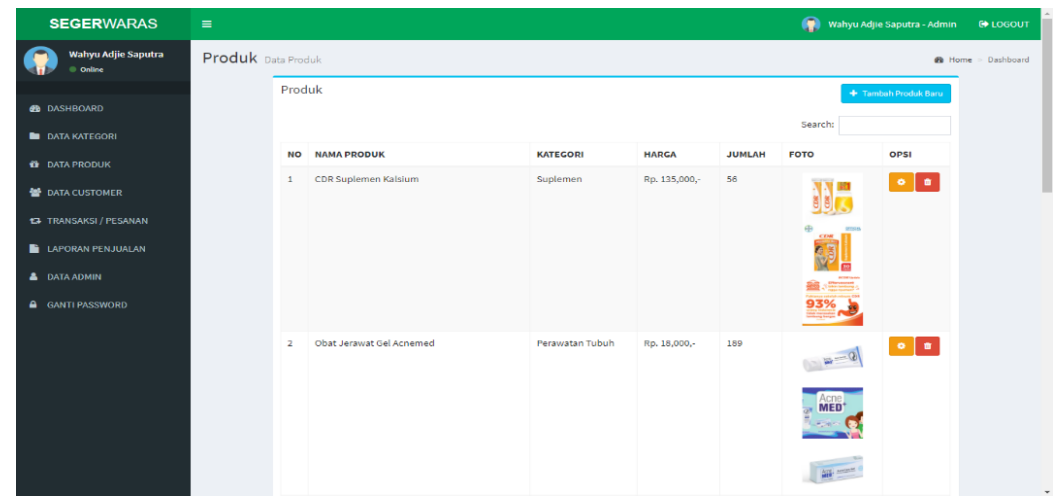

Figure 20. Product Data Page

On this product data page, the admin can input new product data or edit old product data that has been stored. The product data display displays the name, quantity, price, photo, product description, input date, and product expiration dateThe customer data page displays a list of customers who have registered into the system. On this page, the data displayed is the name, email, cellphone number, and address, then options for setting and deleting customer data are also on this menu. The customer data page can be seen in Figure 21.

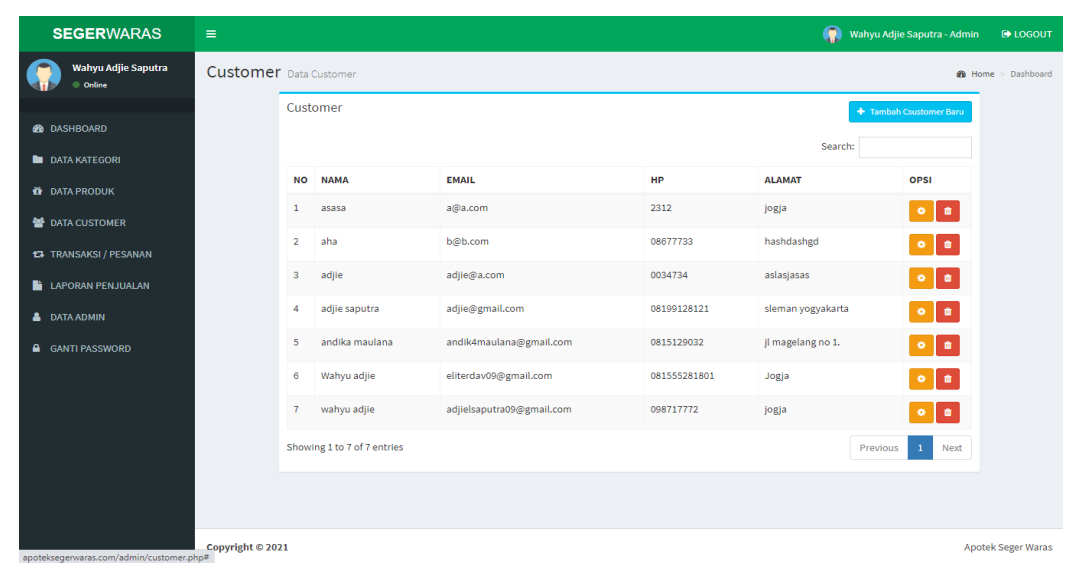

Figure 21. Customer Data Page

This page displays the customer's transactions, and the admin can see the payment status and input the receipt number. This page displays invoice number., date of transaction, name of customer or buyer, total payment, payment status, receipt input, button to print an invoice, and delete button. Transaction and order pages can be seen in Figure 22.

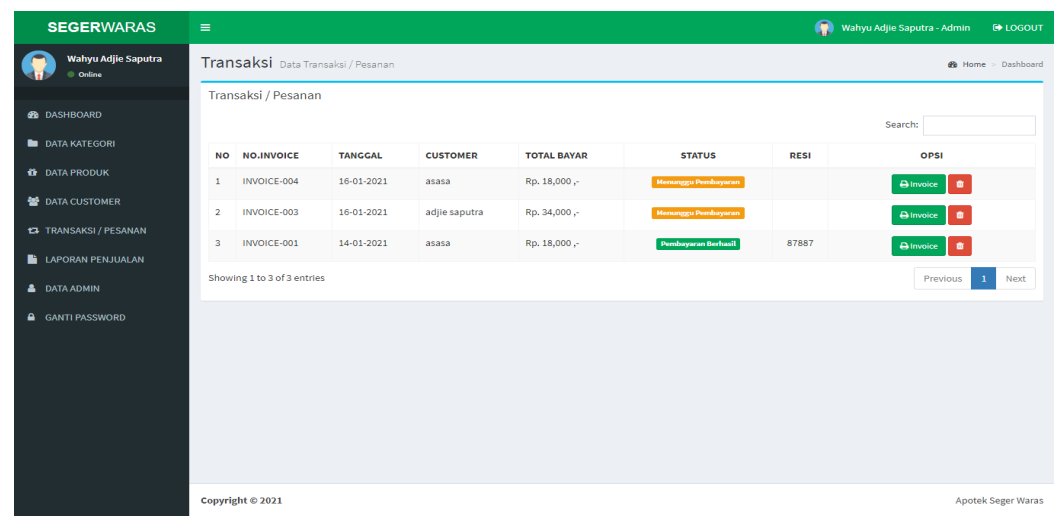

Figure 22. Transaction and Orders Page 
The sales report page displays all transaction data made in the system. On this sales report page, the admin can search for transaction data by date to make it easier to print sales reports or find old transaction data. All transaction data made with successful or unsuccessful payment status will be displayed here. The sales report page can be seen in Figure 23.

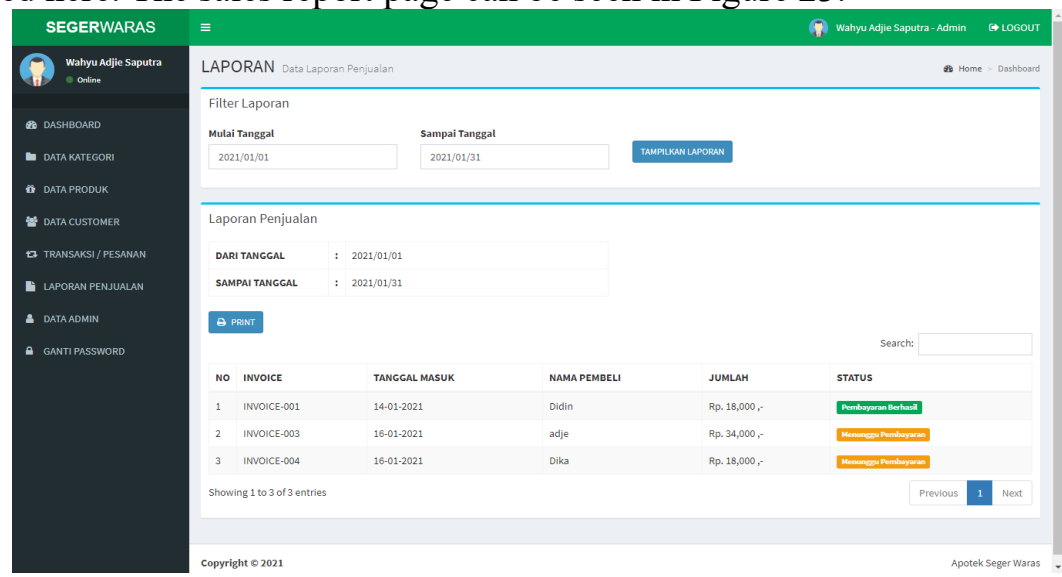

Figure 23. Sales Report Page

This page displays data of users who can access the admin page and add new users. Data displayed in the form of name, username, photo, edit options. The add user field consists of inputting username, password, user name, and photo. The admin data page can be seen in Figure 24.

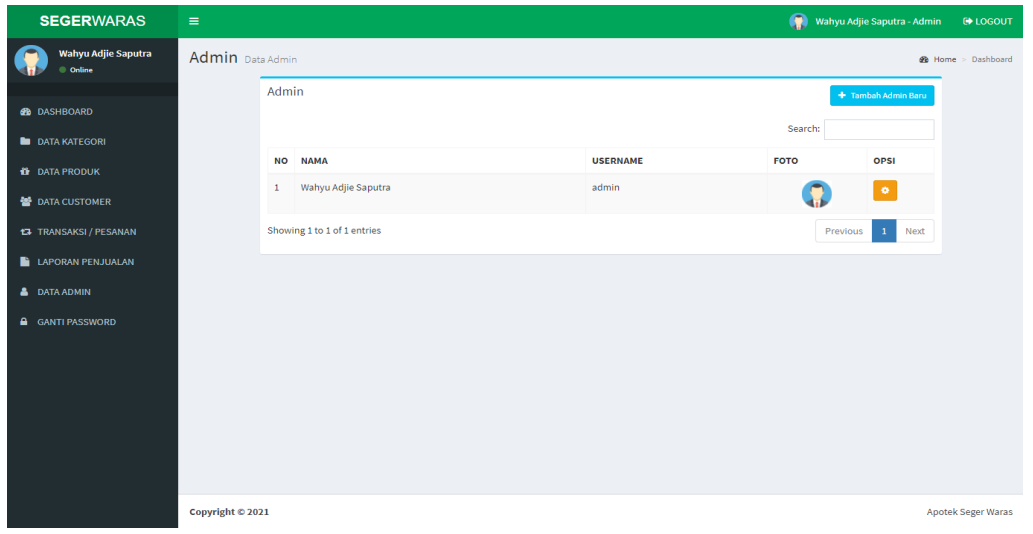

Figure 24. Admin Data Page

On this page, the admin can change the password that is currently in use. The admin who can change the password on this menu is only the admin who is currently logged in and cannot change other admins' passwords. Change password page can be seen in Figure 25.

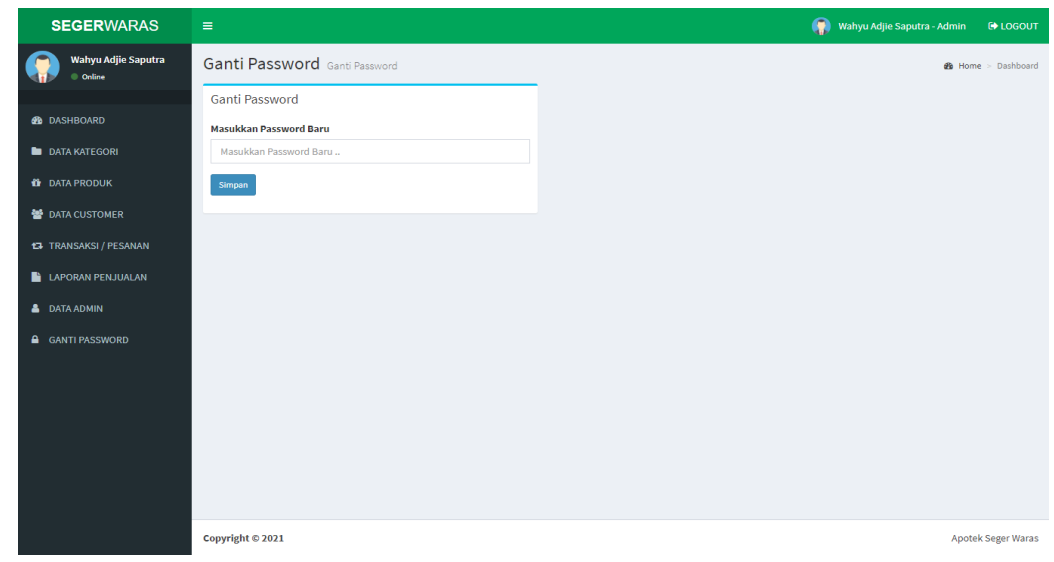

Figure 25. Change Admin Password 


\section{CONCLUSION}

This research produces a prototype and design of an online pharmacy development using a website. Based on the discussion that has been conveyed, the application developed can make it easier to search for drugs and their descriptions such as content, uses, how to use, and visuals of the drug being searched. Besides, the "Seger Waras" Pharmacy Website can make payment transactions with a payment gateway service. Thus, the customers can choose to pay online via bank transfer or offline via Indomaret or Alfamart. Likewise, in reporting, pharmacies can know the details of sales clearly and accurately. This prototype will still be developed with the concept of a mobile application and additional features for calculating profit and loss and prediction.

\section{REFERENCES}

[1] A. T. Hidayat, A. M. D. Dewantara, and S. Saifullah, "The Development of Website on Management Information System for E-commerce and Services," J. Sisfokom (Sistem Inf. dan Komputer), vol. 9, no. 3, pp. 380-386, Oct. 2020, doi: 10.32736/sisfokom.v9i3.992.

[2] A. T. Hidayat, A. Nugroho, and S. Saifullah, "Web development based on sdlc concept approach in ecommerce at Basuki Jaya Pharmacy," Int. J. Eng. Technol. Nat. Sci., vol. 2, no. 1, pp. 1-7, 2020.

[3] A. Nasution and T. Baidawi, "Sistem Informasi Penjualan Obat Berbasis Web Pada Apotek Perwira Jaya Bekasi," INFORMATICS Educ. Prof. J. Informatics, vol. 1, no. 1, pp. 70-83, 2016, [Online]. Available: http://www.ejournal-binainsani.ac.id/index.php/ITBI/article/view/145.

[4] P. D. Astuti, "Sistem Informasi Penjualan Obat Pada Apotek Jati Farma Arjosari," Speed-sentra Penelit. Eng. dan edukasi, vol. 3, no. 4, 2017.

[5] S. Siswati, "The analysis service implementation by the apotheker in private apotek in padang city online based in 2019.” Redwhite Press PP - Jakarta, 2020, doi: https://doi.org/10.32698/tech3244.

[6] Istianingsih and D. T. Untari, "Implementation of Hierarchy Analytical Process (Ahp) Method for Determine The Preferences of Choosing Online Pharmacy in Bekasi, West Java," Eur. J. Mol. Clin. Med., vol. 7, no. 2, pp. 4858-4862, Nov. 2020, [Online]. Available: https://ejmcm.com/article_3070.html.

[7] Y. Fauziah, S. Saifullah, and A. S. Aribowo, "Design Text Mining for Anxiety Detection using Machine Learning based-on Social Media Data during COVID-19 pandemic," in Proceeding of LPPM $U P N$ “Veteran” Yogyakarta Conference Series 2020-Engineering and Science Series, 2020, vol. 1, no. 1, pp. 253-261, doi: 10.31098/ess.v1i1.117.

[8] S. Saifullah, Y. Fauziah, and A. S. Aribowo, "Comparison of Machine Learning for Sentiment Analysis in Detecting Anxiety Based on Social Media Data," Jan. 2021, [Online]. Available: http://arxiv.org/abs/2101.06353.

[9] H. Singh, A. Majumdar, and N. Malviya, "E-PHARMACY IMPACTS ON SOCIETY AND PHARMA SECTOR IN ECONOMICAL PANDEMIC SITUATION: A REVIEW,” J. Drug Deliv. Ther., vol. 10, no. 3-s, pp. 335-340, Jun. 2020, doi: 10.22270/jddt.v10i3-s.4122.

[10] M. M. Khan, M. R. Amin, A. Al Mamun, and A. A. Sajib, "Development of Web Based Online Medicine Delivery System for COVID-19 Pandemic," J. Softw. Eng. Appl., vol. 14, no. 01, pp. 26-43, 2021, doi: $10.4236 /$ jsea.2021.141003.

[11] H. S. Song and B.-M. Lee, "The Viability of Online Pharmacies in COVID-19 Era in Korea," Int. J. Heal. Policy Manag., Jan. 2021, doi: 10.34172/ijhpm.2020.260.

[12] S. F. W. Nainggolan, E. Hernawati, and A. P. Kurniawan, "Aplikasi Pengadaan dan Penjualan Obat Berbasis Web (Studi Kasus: Apotek Siliwangi)," in e-Proceeding of Applied Science, 2018, pp. 15441550.

[13] I. H. Sambiu and Y. Amir, "Sistem Informasi Pesediaan Obat Pada Puskesmas Kalumata Berbasis Web,” J. Ilm. Ilk. - Ilmu Komput. Inform., vol. 1, no. 1, Jan. 2018, doi: 10.47324/ilkominfo.v1i1.2.

[14] M. D. Mendoza and T. T. A. Putri, "Payroll System Design With SDLC (System Development Life Cycle) Approach,” J. Mantik, vol. 4, no. 1, pp. 27-32, 2020.

[15] O. J. Okesola, A. A. Adebiyi, A. A. Owoade, O. Adeaga, O. Adeyemi, and I. Odun-Ayo, "Software Requirement in Iterative SDLC Model," pp. 26-34, 2020, doi: 10.1007/978-3-030-51965-0_2.

[16] P. McLeod, "Download E-Commerce : Business , Technology, Society ( 4th Edition )," no. 2004, pp. 2-5, 2009.

[17] E. Turban, D. King, J. K. Lee, T.-P. Liang, and D. C. Turban, Electronic Commerce - A Managerial and Social Perspective. 2015.

[18] R. S. Pressman, Software Quality Engineering: A Practitioner's Approach. 2010.

[19] H. Hartono, "Pengertian Website dan Unsur-Unsurnya," Ilmu Teknol. Inf., pp. 1-7, 2013. 
[20] N. J. Simanjuntak, S. Suryadi, and G. J. . Silaen, "SISTEM PENGARSIPAN SURAT BAGIAN ORGANISASI DAN TATALAKSANA PADA KANTOR BUPATI LABUHANBATU BERBASIS WEB," J. Inform., vol. 5, no. 3, pp. 26-36, Oct. 2019, doi: 10.36987/informatika.v5i3.733.

[21] I. Kurniawan, Humaira, and F. Rozi, "REST API Menggunakan NodeJS pada Aplikasi Transaksi Jasa Elektronik Berbasis Android," JITSI J. Ilm. Teknol. Sist. Inf., vol. 1, no. 4, pp. 127-132, Dec. 2020 , doi: 10.30630/jitsi.1.4.18.

[22] Y. Gamaliel and S. Suakanto, "Perancangan dan Implementasi Payment Gateway dengan metode Concurrency untuk Transaksi Nontunai,” J. Telemat., vol. 12, no. 1, pp. 39-46, 2017. 